\title{
Working on heterogeneous human capital
}

\author{
Citation for published version (APA):
}

Heijke, J. A. M. (2008). Working on heterogeneous human capital. ROA. ROA Technical Reports No. 006 https://doi.org/10.26481/umarot.2008006

Document status and date:

Published: 01/01/2008

DOI:

10.26481/umarot.2008006

Document Version:

Publisher's PDF, also known as Version of record

\section{Please check the document version of this publication:}

- A submitted manuscript is the version of the article upon submission and before peer-review. There can be important differences between the submitted version and the official published version of record.

People interested in the research are advised to contact the author for the final version of the publication, or visit the DOI to the publisher's website.

- The final author version and the galley proof are versions of the publication after peer review.

- The final published version features the final layout of the paper including the volume, issue and page numbers.

Link to publication

\footnotetext{
General rights rights.

- You may freely distribute the URL identifying the publication in the public portal. please follow below link for the End User Agreement:

www.umlib.nl/taverne-license

Take down policy

If you believe that this document breaches copyright please contact us at:

repository@maastrichtuniversity.nl

providing details and we will investigate your claim.
}

Copyright and moral rights for the publications made accessible in the public portal are retained by the authors and/or other copyright owners and it is a condition of accessing publications that users recognise and abide by the legal requirements associated with these

- Users may download and print one copy of any publication from the public portal for the purpose of private study or research.

- You may not further distribute the material or use it for any profit-making activity or commercial gain

If the publication is distributed under the terms of Article $25 \mathrm{fa}$ of the Dutch Copyright Act, indicated by the "Taverne" license above, 


\title{
Working on heterogeneous human capital ${ }^{*}$
}

\author{
Hans Heijke
}

ROA-TR-2008/6

December 2008

* English version of 'Werken aan heterogeen menselijk kapitaal', valedictory lecture presented on 16 May 2008 by Hans Heijke, Professor of Education and the Labour Market at Maastricht University

Research Centre for Education and the Labour Market

P.O. Box 616

6200 MD Maastricht

The Netherlands

E-mail: $\quad$ secretary@roa.unimaas.nl

Internet: www.roa.unimaas.nl

Maastricht University

Faculty of Economics and Business Administration 
(C) Hans Heijke, Maastricht, 2008.

All rights reserved. No part of this publication may be duplicated, stored in an electronic data file or published without prior written permission from its author.

ISBN 978-90-5321-472-5

Sec09.007 


\section{Contents}

1 Introduction 1

2 Social and scientific context 3

3 From planning instrument to forecasting model 6

4 Discrepancies between supply and demand 11

5 Forecasts of labour market perspectives 14

6 Competencies 21 



\section{Introduction}

At the beginning of the nineteen-eighties, the Dutch economy was in a poor state. Successive oil crises had hit the industrial sector particularly hard. This prompted government to set up an authoritative committee, led by former Shell president Wagner. The committee was asked to advise on the creation of a new industrial élan and revitalisation of the economy. One of the committee's recommendations was a better match between education and occupational practice, in order to benefit sufficiently from the contribution of education and training to economic development. ${ }^{1}$ In the wake of these recommendations, the ministry of Education decided to commission the economics faculty of Maastricht University with a longterm research assignment, the primary aim of which was to make the labour market more transparent for education decisions.

The founding dean of the economics faculty and former minister of Social Affairs, Wil Albeda, asked me to set up this research project and to create a research centre within the faculty to carry out the project. ${ }^{2}$ At that time - having graduated from the University of Amsterdam - I worked for NEI (Netherlands Economic Institute) in Rotterdam. At this institute, I headed the department of Labour Market Research, which I had also set up. Having led this thriving research group for thirteen years, I was ready for a new challenge that would get me even closer to a university research environment. In 1986, the project was ready to start in Maastricht and I made the switch from NEI to this university. A year later, I was appointed professor of Education and the Labour Market.

The research centre to be set up, became the Research Centre for Education and the Labour Market (ROA), which I have led for more than twenty years. ROA's

1. Commissie Wagner (1984), Op weg naar een gezamenlijke verantwoordelijkheid. Eindrapport van het Open Overleg over de voorstellen van de commissie Wagner inzake het beroepsonderwijs. The Hague: Ministry of Education and Science.

2. Heijke, J.A.M. (1985), Het project onderwijs en arbeidsmarkt van de Rijksuniversiteit Limburg informatierapport. Krimpen aan den IJssel. 
inspiring research environment and the many opportunities it offered for working together with enthusiastic colleagues, gave me enough room to also devote myself to my greatest passion: doing research. In this valedictory lecture, I would like to share with you some thoughts on a number of topics my colleagues and I worked on, hoping to have made a contribution to a more transparent relationship between education and the labour market.

Initially, ROA's research concentrated primarily on making forecasts of future labour market perspectives for education programmes in secondary and tertiary education. At a later stage, new themes were added, including 'education and occupational career' and 'training and work'. These last two themes have meanwhile received their own chairs, for which inaugural lectures have been held. ${ }^{3}$ In my valedictory lecture, I would therefore like to focus on the education and labour market project in which I have been actively involved for many years. This project is still a very important research activity for ROA and has developed into an authoritative national source of information on the labour market perspectives of education programmes, with an exemplary function for other countries both within and outside Europe. ${ }^{4}$

In my description of this project, I will discuss the following topics: the social and scientific context of the project, the setup of the forecasting model and the concept of discrepancy used, the presentation of the labour market forecasts and their use.

3. Rolf van der Velden (2006), Generiek of specifiek opleiden?, lecture given on the occasion of his accepting the post of professor holding the endowed chair of Education and Occupational Career at the Faculty of Economics and Business Administration of Mastricht University, and Andries de Grip (2000), Van tweedekansonderwijs naar een leven lang leren, lecture given on the occasion of his accepting the post of professor holding the endowed chair of In-company and Vocational Training and the Labour Market, respectively.

4. An impression of the international state of the art with respect to labour market forecasting by education and occupation, is given in: Heijke, H. (ed.) (1994), Forecasting the labour market by occupation and education, The forecasting activities of three European labour market research institutes. Boston/Dordrecht/London: Kluwer Academic Publishers, and more recently: Neugart, M., Schömann, K. (eds) (2002), Forecasting labour markets in OECD countries, Measuring and tackling mismatches. Cheltenham (UK) / Northampton (MA, USA): Edward Elgar. 
Linked with the project of Education and the Labour Market, I will complete my lecture by discussing my own research line on the role of competencies in the labour market and their acquisition in education.

\section{Social and scientific context}

Labour economics, in principle, offered two approaches for gaining insight in the education programmes that were most suitable for investments. The first method is the rate of return approach, developed within the framework of the human capital theory, which has become widely known in particular because of the work done by Becker (1964) and Mincer (1974)..$^{5}$ The second approach concerns the manpower requirements method, developed among others by Parnes (1962), with the aim of solving practical planning issues of where to invest in education in order to maximise the contribution to national or regional economic developments. ${ }^{6}$

In the rate of return approach, the wage development across the entire working lives of individuals is deduced from the added value of education in the labour market. Just like in the case of material capital investments, this added value is expressed in terms of the internal rate of return. This is the rate of return that equals the market value of future yields - in the form of wages - to the market value of the incurred costs, consisting in particular of lost income during education or training.

In the manpower requirements method, the first step is to determine a target economic growth rate for the planning period. Then, it is deduced how much labour would be required in the various economic sectors and occupations within these sectors, in order to achieve this growth. After this, the most suitable education programme is selected for each occupation. The labour demand for each occupation can then be translated into the labour demand in terms of education.

5. Becker, G.S. (1964), Human Capital: a theoretical and empirical analysis, with special reference to education. New York: NBER; Mincer, J. (1974), Schooling, experience and earnings. New York: NBER.

6. Parnes, H.S. (1962), Forecasting of educational needs for economic and social development, Paris: OECD. 
After determining this future labour demand, a forecast is made of the labour supply. This concerns the future size of the existing labour force, broken down by education programme, complemented with the expected influx from education. In the case of the influx forecasts, the capacity of the education system is assumed to remain unchanged. Setting off the future labour demand by education programme against the future supply of labour, also by education programme, then indicates in which education programmes additional investments should be made in order to achieve the desired economic growth.

Both approaches have advantages and disadvantages. Estimations of the rate of return are based on the relation within the labour force between the wages earned and the education taken. Some education programmes date from a distant past and may not even exist anymore. A more basic problem is the fact that when estimating the rate of return, it does not become clear to what extent this is determined by the level of supply and demand on the various educational submarkets. The supply/demand relationships, however, will shift in the future because of economic growth, technological and organisational innovation, demographic developments and changes in the education system. The rates of return found for the past, will therefore change too. But it is difficult to indicate the direction of this change if no link can be made with those economic, technological and demographic shifts. Another practical disadvantage that played a role at the time, was the fact that the statistical data that were needed to be able to estimate the rates of return, were rarely available. And if they were available, the data only related to educational levels, without substantial differentiation by field of education.

The description of the manpower requirements approach above, shows that these future shifts in supply and demand were taken into consideration. The economic contribution of education programmes, however, is only considered for the planning period. This is generally much shorter than the period in which graduates from those education programmes operate in the labour market. Making labour market forecasts for a period of - say - forty years, is a dicey task. The econometric 
tools, however sophisticated, will prove less predictable than a crystal ball. It is true that the margins of error can be reduced by shortening the forecasting period. But this decreases the advantage of the manpower requirements method over the rate of return approach. After all, in that case, the shifts in the relationships between supply and demand on the labour market and the changes in the education programmes offered are smaller.

A theoretical solution would be to integrate the two approaches analytically. This is frustrated, however, by the statistical data. The Education and Labour Market project demands highly detailed data on the labour market perspectives of education programmes. In principle, the information provided should cover the entire spectrum of programmes in secondary and tertiary education. In addition, the statistical basic data should be refreshed regularly to keep the models up to date. The available data sets that meet these requirements, however, do not contain wage details. That is why the manpower requirements method was selected as the starting point.

As said above, the manpower requirement approach is a tool that fits in the ideology of a planning government. The stagnating economic developments in the nineteen-eighties, while public spending was getting out of hand, prompted a change of course in terms of policies. Keynesian spending recipes and direct government support for failing companies were exchanged for policies aimed at increased influence of market forces and a receding public sector. This idea is in line with the gaining of independence and scaling-up of public facilities, including education. There is no longer a role for government as central planner, but merely as a guardian of an efficient free market system. An indispensable element for a good result, however, is that all market parties are well informed. In other words, the market should be transparent for them. By providing information on future labour market perspectives of education programmes, ROA could contribute to the optimisation of the match between education and the labour market. So, a better match between the investments in education programmes by both students and 
educational institutes and the possibilities of the labour market. And also a better match between the investments by companies in new personnel and the output from education.

Favouring the manpower requirements approach over the rate of return approach, did not mean that the human capital theory would not play a role in the research done by ROA. On the contrary, I would say. Both within and outside the Education and Labour Market project, the idea that completing an education programme is in itself an investment that may yield results in the future, played an important role.

\section{From planning instrument to forecasting model ${ }^{7}$}

The conversion of the traditional manpower requirements model from a planning instrument into a forecasting model, implied that a number of important choices needed to be made.

The first choice concerned the length of the forecasting period. Obviously, the longer the forecasting period, the more uncertain the outcome. In the case of a forecasting period of more than ten years, the econometric model used would soon no longer be more reliable than the crystal ball. The choice was therefore made to take as short a forecasting period as possible, while still yielding sufficient relevant information. This period was set at five years, allowing the forecasts to create an image of the labour market over a period in which an education programme of average length could be completed.

7. For an elaborate account of ROA's labour market forecasts, see Cörvers, F., Grip, A. de, Heijke. H. (2002), Beyond manpower planning: a labour market model for the Netherlands and its forecasts to 2006, in: Neugart, M., Schömann, K. (eds), Forecasting labour markets in OECD countries. Cheltenham: Edward Elgar, 185-223. A more recent account is: Cörvers, F., et al. (2006), Methodiek arbeidsmarktprognoses en -indicatoren 2005-2010, ROA-W-2006/6. Maastricht: ROA. The key concepts of discrepancy and substitution are explained in detail in: Cörvers, F., Heijke, H. (2004), Forecasting the labour market by occupation and education: Some key issues, ROA-W-2004/4. Maastricht: ROA. 
Because of the difficulty of forecasting labour market dynamics, it is important to keep a finger on the pulse. The forecasts should be repeated regularly for continually progressing, overlapping periods. In the case of an annual approach, the predicted changes in labour market perspectives of education programmes would be relatively limited. Hence the decision to use a biennial schedule. The intermediate year could then be used for a critical evaluation of the previous forecasts and for fundamental research to improve the models used.

The next choice concerned the explicit distinction of the replacement demand for labour alongside the expansion demand. This was an implication of the fact that the focus was on the future labour market position of the graduates who enter the labour market from the education system during a particular period. The room for this influx of newcomers on the labour market is determined not only by the expansion or shrinking of employment in the various economic sectors and occupations. Also important is the availability of jobs caused by the outflow of existing workers, because of retirement, disability, assuming care tasks, etc. To a considerably larger extent than was customary with the traditional manpower requirements method, ROA paid attention in its forecasts to modelling the replacement demand for labour caused by this outflow from the labour market. ${ }^{8}$ This was not merely a question of statistical refinement. No less than three quarters of the number of vacancies for youngsters entering the labour market is determined by the replacement demand. ' This means that economic expansion and contraction processes have relatively less effect on the labour market perspectives of graduates than a relatively accurately predictable demographic development.

The third choice concerned the core of the forecasting model: the substitution issue. The traditional manpower requirements model, as used for forecasting purposes, is in fact more of a calculation model than an economic model that

8. See, for example Willems, E.J.T.A., Grip, A. de (1993), Forecasting replacement demand by occupation and education, International Journal of Forecasting, 9 (2), 173-185.

9. This share may differ widely between occupations and education programmes. 
reflects the behaviour of market parties. The manpower requirements model assumes fixed relationships between production in an economic sector and employment in various occupations. It also assumes fixed relationships between these occupations and the education programmes required for these occupations. This approach was severely criticised by academics right from the start. ${ }^{10}$ Technological developments may change the educational requirements for occupations. This means that different education programmes may become more suitable for these occupations, or education programmes at higher levels are preferred. In addition, there is generally no imperative one-to-one relationship between occupation and education. For a particular occupation, graduates from different education programmes may be employed. Graduates from a particular education programme may also switch from one occupation to another. These substitution options, however, are not perfect, but differ from one occupation to another and from one education programme to another. ${ }^{11}$

For example, a school training students for the butcher's trade gives its graduates a number of job-specific competences that provide them with a comparative advantage in jobs in the butcher's trade. This means that they are able to do their jobs better and more effectively than individuals with different job-specific competences, such as those aimed at the shoe trade. It is in the labour market's interest that school-leavers who have been trained as butchers work in the butcher's trade and those who have been trained as shoemakers in the shoe trade. If they were to exchange jobs, labour market allocation would be suboptimal, resulting in

10. E.g. Blaug, M. (1967), Approaches to educational planning, Economic Journal, 77 (June), 262-287. For a reaction by ROA on more recent criticism, see Borghans, L., Grip, A. de., Heijke, H., Alice in prognoseland. Over de zin en onzin van arbeidsmarktprognoses, ROA-W-2000/6. Maastricht: ROA.

11. For a basic analysis of the substitution issue in the case of heterogeneous human capital, see Dupuy, A. (2004), Assignment and substitution in the labour market, ROA Dissertation Series No. 4. Maastricht: ROA. This builds on the work by Roy, A. (1950), The distribution of earnings and of individual output, Economic Journal, 60 (3), 489-505; Tinbergen, J. (1956), On the theory of income distribution, Weltwirtschaftliches Archiv, 77 (1), 156-175; Tinbergen, J. (1975), Income distribution: analysis, and policies. Amsterdam: North-Holland; Sattinger, M. (1975), Comparative advantage and the distribution of earnings and abilities, Econometrica, 43 (3), 455-468; Sattinger, M. (1993), Assignment models of the distribution of earnings, Journal of Economic Literature, (31 (2), 831-880; Rosen, S. (1978), Substitution and the division of labor, Economica, 45, 235-250. 
unfavourable effects on labour productivity. However, allocation on the labour market will not easily follow this extreme example. After all, the butcher and the shoemaker who work in each other's fields, will earn less than their more productive colleagues who do work in their own occupational domains. But if there is a great scarcity of butchers and a great surplus of shoemakers, one will undoubtedly find shoemakers working in the butcher's trade. They may compensate the relatively lower wages compared to their colleagues who were trained in the butcher's trade, by gaining experience and training to acquire the missing expertise.

The options for substitution between graduates from different education programmes, depends on the extent to which the acquired expertise can be transferred to other occupational domains. The transferability of expertise to each other's occupational domain will not be great between butchers and shoemakers. Transferability will be much greater, however, for expertise acquired in agricultural studies with respect to expertise acquired in horticultural studies. Graduates from both studies can therefore often be found in each other's occupational domain.

The importance of generic competences, such as communicative skills, also plays a role in the substitution options. Within a particular occupational domain, having generic competences may be much more important than having the required fieldspecific knowledge of a particular education. If such generic competences are also taught in other studies, one can easily find graduates from those other studies in this specific occupational domain. As said before, working outside one's occupational domain comes at a price. This price may be lower productivity, with corresponding lower wages. To avoid this, adjustment costs will need to be incurred by gaining work experience and additional training.

The substitution mechanism not only works between studies and occupations at the same level. As a result of shortages on the labour market, which may result in a relative scarcity of higher educated workers, those with an education at 
intermediate level may find employment in the occupational domains of a higher education. Conversely, in the case of a surplus of higher educated graduates, those educated at the intermediate level may be forced out of their occupational domains. The substitution options on the labour market therefore have both a directional dimension and a level dimension. This level substitution will also have an impact on the productivity and wages of graduates. But in this case with regard to the graduates from the variety of education levels working within the same occupation.

I hope that this argument on the substitution issue has made it clear that the existing flexibility on the labour market makes the assumption of a one-to-one relationship between occupation and education too strict. This should therefore be taken into account when making labour market forecasts.

The insight that there are more or less extensive substitution options between studies and occupations, has been used by ROA to create a classification in the statistic data to be used. On the basis of the relationship between occupations, apparent from the range of education programmes from which workers are recruited for these occupations, clustering methods were used to create a more condensed classification of occupations. ${ }^{12}$ In a similar way, based on the relationship between education programmes, apparent from the range of occupations in which graduates find jobs, a more condensed classification of education programmes was created. ${ }^{13}$ As a result of this condensing of statistic data, we were able to distinguish relatively homogeneous submarkets in terms of labour market position. In this way, we were also able to populate sufficient cells in the education by occupation matrix. After all, this matrix is deduced from a - for our purpose - relatively small sample file, the Enquête BeroepsBevolking (EBB, or Labour Force Survey) by Statistics Netherlands. This eventually resulted in the

12. Grip, A. de, Groot, L.F.M., Heijke, J.A.M. (1991), 'Defining occupational groupings by educational structure', Environment and Planning A, 23, 59-85.

13. Heijke, H., Matheeuwsen, Willems, E. (2002), Clustering educational categories in a heterogeneous labour market, Education Economics, 10 (3), 89-108. 
possibility to make forecasts of the labour market perspectives for all regular education programmes. So from primary education to higher education. This classification distinguishes approximately 100 types of education programmes and 130 groups of occupations.

The complex substitution mechanisms between education programmes and occupations, discussed above, were processed by ROA in its forecasting model. This took into account both the level dimension and the direction dimension of these mechanisms. The complexity derives in particular from the fact that the inclusion of the substitution process in the models used, creates interrelationships between the various submarkets of the labour market. ${ }^{14}$ However, as the EBB does not contain any wage data, the approach is not perfect yet. One thing Lex Borghans and I were able to determine after studying a number of variants, was that the existing method of processing the substitution mechanism at least yielded better forecasts than the traditional manpower requirements model. ${ }^{15}$ It would be good, however, if the EBB were enriched with wage data. A temporary solution may be to relate the results of analyses of micro data files which include not only data on education and occupation, but also wage data, to the EBB file. I would say that a considerable step forward is still to be made.

\section{Discrepancies between supply and demand}

One aspect that was adopted from the traditional manpower requirements approach, concerns the concept of discrepancy. This means that the future labour market perspective of an education programme is represented by means of the expected difference between supply and demand of graduates from this education programme. ${ }^{16}$ This implies that no future impression is given of the labour market

14. In fact, this is about algorithms that help gradually achieve a stable final state.

15. Borghans, L., Heijke, H. (1996), Forecasting the educational structure of occupations: a manpower requirement approach with substitution, Labour, 10 (1), 151-192.

16. As indicated before, the demand for graduates is the sum total of the expansion demand and replacement demand. 
as it would be after full adjustment of supply and demand. The reason is that it cannot be predicted with sufficient accuracy how this adjustment would take place and how extensive this adjustment would be. I will explain this adjustment process in greater detail below.

In the case of a shortage of graduates in a particular educational submarket, an upward wage reaction may occur. The higher wages may encourage others to take the same study or may elicit additional supply from other schools. At the demand side of the labour market, the higher rates for graduates from a particular study may entice employers to resort to related studies at a lower level. The introduction of different production methods and reorganisation of the work can also save on the deployment of graduates from the study concerned. However, adjustments will not only be through the wage mechanism. Other labour conditions may take over this role, such as offering full-time employment or tenure. The effects of these adjustment mechanisms may be hindered by the fact that wages and other labour conditions can only be adjusted to a limited extent because of institutional factors. In addition, lack of market transparency may lead to insufficient information on existing conditions on the labour market. A shortage of labour may then continue to exist for a long time.

Wage adjustments therefore provide a limited and possibly incorrect view of the labour market perspectives of a study and the effects on graduates. The discrepancy between supply and demand of labour, on the other hand, does provide the 'correct' view of these perspectives, but this is not specified by types of adjustment. Partly because wage details are missing in the data set to be used, it was decided to use the discrepancy approach. In a certain way, this takes into account the existence of substitution between studies as a result of expected discrepancies between supply and demand, but this is not the place to discuss this in greater detail.

On the basis of what has been said on the adjustment process, a forecasted discrepancy between supply and demand as a measure of the future labour market 
perspectives of a study, must be interpreted as follows. In the case of a forecasted shortage of graduates from a study, graduates from that study may expect to quickly find jobs within their occupational domain and at their education level, so without first being unemployed. They also have a greater chance of full-time employment and tenure at relatively high wages. In the case of a forecasted surplus, the situation is the opposite. Graduates have a greater chance of a period of unemployment and may have to resort to jobs outside their occupational domain or below their educational level. There is also a greater chance of temporary parttime employment and lower wages.

The adjustment process described above may seem rather trivial. Nevertheless, mistakes are often made in this area in practical policy-making. For example, a forecasted future discrepancy between supply and demand in an educational submarket often leads to the conclusion that therefore additional supply must be trained in order to stop the expected gap. In the case of a forecasted future shortage of 10,000 teachers, an additional 10,000 graduates should leave the teacher training colleges. What is overlooked, is the effect of the adjustment process at the supply side, which may lead to additional supply from elsewhere (lateral entry, return to work). Another thing that is overlooked, is the fact that part of the demand for teachers may be reduced by increasing class sizes. Training an additional 10,000 teachers would then turn the expected shortage into a surplus. In a study that I did together with Andries de Grip, I made an estimate of this adjustment elasticity. ${ }^{17}$ It turned out that, on average, an additional supply of graduates from a study to the labour market of approximately $30 \%$ of the labour shortage, was sufficient to restore the balance on the educational submarket.

17. Heijke, H., Grip, A. de (1995), 'Mismatches between education and the labour market', in: Jaspers, T., Schippers, J., Siegers, J., Berkel, I. van (eds) (1995), Working policies?. Groningen: Wolters-Noordhoff, 51-80. 


\section{Forecasts of labour market perspectives}

To make it easier for those who need to choose a study to interpret the forecasted discrepancies, and to take into account the margin of error in the forecasts, qualitative characterisations are assigned to the quantitative forecasting results. These characterisations, ranging from a forecasted large shortage to a forecasted large surplus are as follows: Very Good, Good, Reasonable, Moderate and Poor labour market perspectives.

\section{Figure 1}

Overall setup of the forecasting model

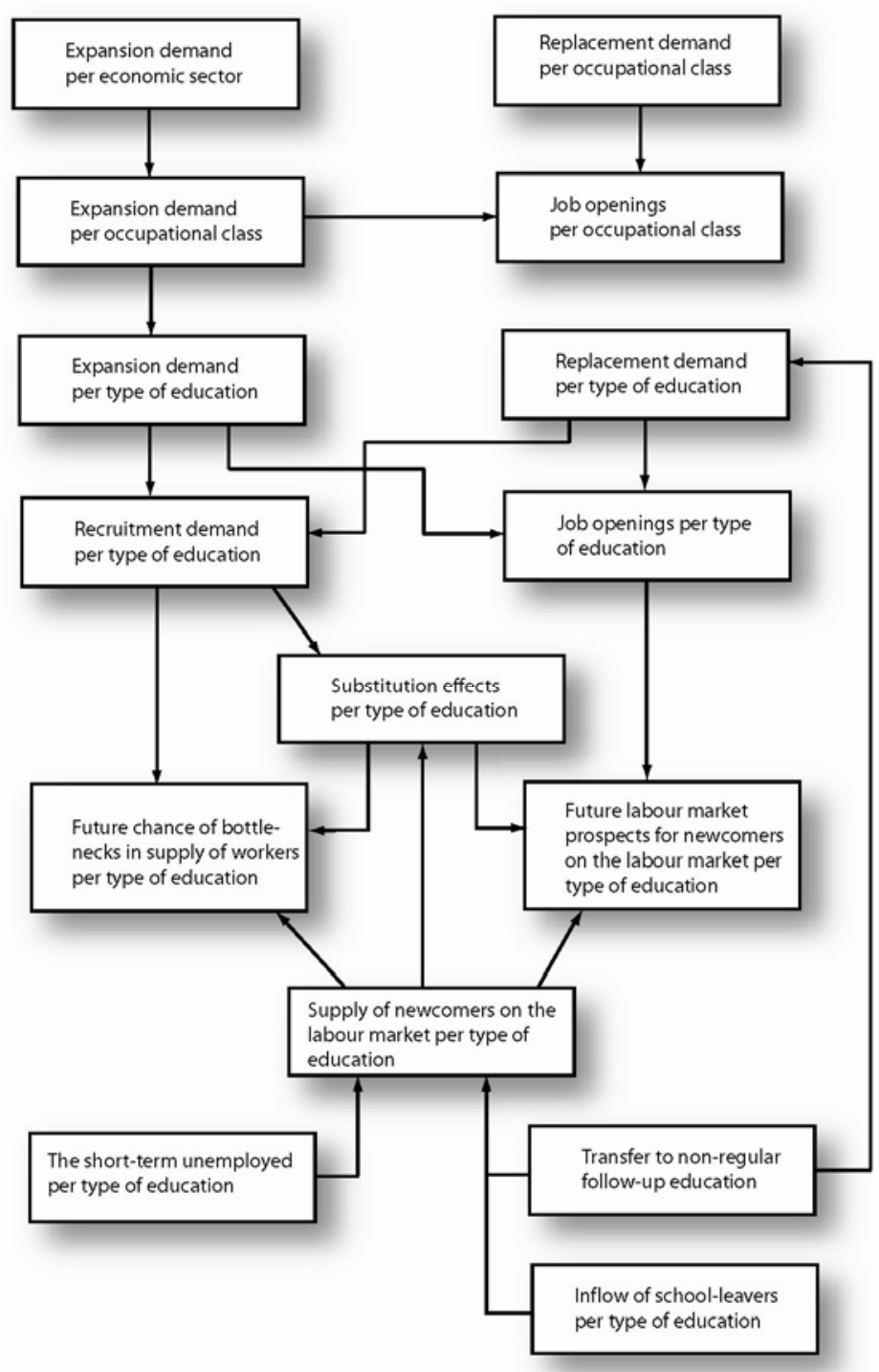


A diagram of the forecasting model used is presented in Figure 1. Having already elaborated on its essential elements, the diagram will not be discussed here.

A summary of the most recent labour market forecasts has been included in Table $1 .{ }^{18}$ For every education level, the percentages of graduates with an expected good to very good labour market perspective, have been represented. The percentages are based on all individual 102 types of studies. For greater clarity, the percentages displayed have not been differentiated by field either. To be able to detect a development, two (overlapping) subperiods have been distinguished: 2005-2009 and 2007-2011. The first period has largely been completed, while most of the second one is still in the future. It is expected that, on average, the labour market perspectives for studies will improve in the years to come: The percentage of graduates with good to very good perspectives increases from $24 \%$ to $44 \%$. In particular for school-leavers from Higher Secondary General Education (HSGE) and Pre-University Education (PUE) who enter the labour market, the perspectives are favourable. However, this is only a small group, because the large majority $(85 \%)$ continue their education in Higher Vocational Education (HVE) or University Education (UE). Another striking fact is the significant improvement of the labour market perspectives for the higher educated, in particular those from UE. In general, the latter have the best perspectives on the labour market. The only exception is the study of Economics. The perspectives for graduates from Intermediate Vocational Education (IVE), however, are deteriorating and are fairly unfavourable. In particular in the fields of socio-cultural and economic studies, the perspectives are moderate. It is expected that the perspectives for technical studies in particular are favourable. This also applies to Preparatory Intermediate Vocational Education (PIVE). The favourable perspectives for technical studies here is distorted in part by the fact that students enter in the IVE day release

18. When making labour market forecasts, use is made of industry forecasts by CPB Netherlands Bureau for Economic Policy Analysis and EIM Business \& Policy Research, and reference estimates of the outflow from education by the Ministry of Education, Culture and Science. 
studies (the former apprenticeship studies), which in these forecasts is considered as having a job.

\section{Table 1}

Percentage of graduates with an expected good to very good labour market perspective for graduates, by education level, 2005-2009 and 2007-2011

\begin{tabular}{lcc} 
Education level & $2005-2009$ & $2007-2011$ \\
\hline Primary education & $\%$ & $\%$ \\
\hline PIVE & 0 & 0 \\
\hline HSGE/PUE & 28 & 50 \\
IVE & 0 & 100 \\
HVE & 32 & 27 \\
UE & 18 & 45 \\
\hline Total & 27 & 61 \\
\hline & 24 & 44 \\
\hline Source ROA & &
\end{tabular}

How reliable are these forecasts? Naturally, this can only be said with certainty afterwards. As said before, the forecasts made in the past are evaluated regularly, so that lessons can be learned for future forecasting rounds. Table 2 shows some of the results of evaluations made. ${ }^{19}$ Although these evaluations concern all elements of the approach, I will here restrict myself to the forecasted classification of the labour market perspectives of the various types of education.

The table shows for the forecasting years that were evaluated, the percentage of types of education for which the forecast was correct and the percentage for which it was almost correct. Almost correct means that the forecasted characterisation differs no more than one adjacent characterisation from the actual one. For approximately half of all studies, the characterisation of the labour market perspective proved to have been correct, while for approximately $90 \%$ of the studies, it was almost correct. This seems to me quite a satisfactory result. In the

19. Smits, W., Diephuis, B. (2001), Evaluatie arbeidsmarktprognoses naar opleiding en beroep tot 1998, ROA-R2001/2. Maastricht: ROA; Dupuy, A. (2005), An evaluation of labour market forecasts by type of education and occupation for 2000, ROA-W-2005/1E. Maastricht: ROA. 
course of time, the forecasting quality has even improved slightly, although it is important to remain focussed. ${ }^{20}$

\section{Table 2}

Percentage of matches between forecasts and actual results, with respect to the characterisation of labour market perspectives of types of education

\begin{tabular}{|c|c|c|}
\hline Forecasting year & $\begin{array}{c}\text { Same } \\
\text { characterisation } \\
\%\end{array}$ & $\begin{array}{c}\text { No more than one } \\
\text { characterisation difference } \\
\%\end{array}$ \\
\hline 1994 & 45 & 90 \\
\hline 1998 & 52 & 83 \\
\hline 2002 & 64 & 93 \\
\hline
\end{tabular}

Source: Smits and Diephuis (2001), Dupuy (2005)

The biennial forecasts of the labour market perspectives of studies are presented in publicly available reports, entitled The labour market by education and occupation, until the year ... (the most recent one being 2012). ${ }^{21}$ This report is meant in particular for government policy-makers, employment policy organisations, employers/trade unions, and education. In addition to labour market forecasts, the report also details a number of themes relating to the match between education and the labour market. The publication of a new report attracts considerable media interest. The labour market perspectives of studies are included, together with other indicators of the match between education and the labour market, in a variety of information materials for study and career choices, such as the Keuzegids Hoger Onderwijs (studychoice guide higher education) and Studychoice.nl. The information can also be used by employers for their personnel policies. The full collection of data is included in a computerised data set, AIS (labour market information system).

20. Preliminary results for the forecasting year 2004, indicate a deterioration of the forecasting quality of the allocated classifications.

21. Research Centre for Education and the Labour Market (2007), The Labour Market by Education and Occupation until 2012, ROA-R-2007/4. Maastricht: ROA. 
What is the relevance of these data? I will try to illustrate this on the basis of a study by Patrick van Eijs and myself.22 We started from the assumption that employers incur adjustment costs if the match between the education completed by a newly appointed employee and the job to be done is suboptimal. These adjustment costs concern the additional training to be completed both within and outside the job. We also assumed that employers reflect these costs in the wages of new employees. Employees whose education matches their new job less well, therefore receive lower starting wages and need more time to meet the skill requirements of the job than their colleagues whose education matches better. The ideal situation for the labour market as a whole would be if there were such a distribution of studies across occupations that training costs are minimal.

We made use of a data set containing individual details on salaries, education completed, type of job and number of hours worked. ${ }^{23}$ These data were used to estimate the tenure-wage profile, taking into account the type of job and educational background. From the profile found, we then deduced the total training costs in the labour market, given the distribution of studies across occupations. We then used the profile found to determine the total training costs if studies were perfectly distributed across occupations. The difference in training costs between the actual and the optimal distribution of studies across occupations, are then the costs of the mismatch between education and occupation. Taking into account the size of the national workforce in relation to the sample and the wage increase since the time of the survey, we can then estimate the total costs of a mismatch between education and occupation at approximately 10 billion euros. ${ }^{24}$ In my opinion, this amount is high enough to justify a modest investment in greater transparency of the labour market.

22. Eijs, P. van, Heijke, H. (2000), 'Mismatch between occupation and education and the costs and benefits of job-related training', in: Heijke, H., Muysken, J. (eds), Education and training in a knowledge-based economy. Houndmills/London/New York: Macmillan, 159-189.

23. The OSA labour supply panel 1992.

24. Approximately 2000 euros per full-time worker. 
How have the forecasting data been used by students choosing studies? To answer this question, it is important that for individual students who select a study, the data should offer support for their choice of a study that provides personal satisfaction. A study that they will not regret having done afterwards. Because of the long duration of studies, mending a choice that was wrong can only be achieved with great sacrifices.

Personal satisfaction differs from one individual to the next. For some, the labour market perspective is of decisive importance and the content of the study comes second. For others, it is the other way around and the primary importance is the intrinsic experience of the study, while their attitude towards the labour market perspective is neutral. It is also possible to choose a study with a broad labour market perspective. So a study that offers a wide range of options after graduation. Others choose a highly specialised study and accept that this choice may have a great labour market risk in the long term. It is also possible to argue that the concept of labour market perspective applies on average for the educational submarket concerned, but that making a greater effort and having above-average talents allows individuals to improve their chances.

In all those cases in which the labour market perspective plays a role in the decisions, the intention of ROA's labour market information is to provide help in order to arrive at a well-founded decision. A decision that is not based on prejudices, rumours or dreams, but on independent information created professionally and to the best of our knowledge. The aim of the labour market information that is provided is therefore not to force the choice of studies in a particular direction. The information is first and foremost an aid for those who are in the process of choosing a study, to create an idea of the prospects that various studies offer for future labour market positions. It is expected that this will also contribute to a socially better situation, in which the talents of the population in 
education can be developed in the best possible way and the knowledge and skills acquired can be used as productively as possible in the labour market. ${ }^{25}$

I would like to explain the use of ROA's labour market information for the purpose of study and career choices by making an analogy with the planning of a maritime sailing trip. Suppose your yacht is moored in IJmuiden marina, where you completed your education, and you would now like to sail across the North Sea to a suitable destination along the Dutch coast. This would be Scheveningen marina, where you would like to start a job that matches the education that you completed. The almanac published by the famous ROA institute has told you that the wind will blow from the North and the ebb tide will flow at a certain rate. It is good to know that the institute can also tell you how many boats are likely to choose the same destination and how this relates to the number of available mooring places in Scheveningen marina. Of course it remains uncertain whether the wind, currents and number of boats in relation to the available berths will be exactly as ROA has predicted, but all looks well. Current and wind in the back and sufficient mooring capacity in Scheveningen to cater for the number of departing boats. All boats in IJmuiden with the same destination will need to cope with the same currents, wind and available berths. The differences in size and shape of the boats will mean that they do not all sail equally fast and that they cannot all find a mooring place in the harbour equally easily. The job perspectives with the education taken, therefore have an individual component. If you cannot estimate with sufficient accuracy how your boat will behave in the expected circumstances, you consult the study dean for personal advice.

However, you may also prefer, instead of taking the most likely Southerly route to Scheveningen, to opt for an occupation that does not match the education, for example in the naval base in Den Helder. Having sailed beyond the piers of

25. For a basic analysis of the relationship between the information provided on the future labour market perspectives of education programmes and educational choices, see Borghans, L. (1993), Educational choice and labour market information, ROA Dissertation Series No. 1. Maastricht: ROA. 
IJmuiden, you will then need to steer to starboard in a Northerly direction, tacking hard against the current and wind. After all your efforts, the harbour may turn out to be full and you may need to resort to a job in another marina. This could be in Oudeschild on the island of Texel, where there is always a place available and where you may benefit from the current that has changed course in the meantime. Should you find a berth in Den Helder, however, the joy of the result achieved will be no less. On the contrary, your plate of fried rice in the floating harbour restaurant of the naval base might taste considerably better after all your hard work than the multi-course Indonesian dinner at the Bali restaurant in Scheveningen.

This concludes the part of my lecture on the Education and the Labour Market project. I will now briefly discuss my research line: The Role of Competencies in the Labour Market and their Acquisition in Education.

\section{Competencies}

The aim of the research line on competencies is to contribute to the debate on the question which competencies in graduates increase the labour market relevance of a study and which characteristics of an education programme promote the acquisition of these competencies.

The research line does not focus on making an inventory of all competencies that may be relevant for the labour market. Useful outlines on this topic have appeared in the past, such as the collection edited by Nijhof and Streumer, called Key qualifications in work and education (1998) and the collection edited by Rychen and Salganik, called Defining and selecting key competencies (2001). ${ }^{26}$ The research line on competencies, on the other hand, tries to increase the understanding of the role of discipline-specific knowledge compared to competencies of a more generic nature. With respect to the latter, the research line

26. Nijhof, W., Streumer, J. (eds) (1998), Key qualifications in work and society. Dordrecht/Boston/London: Kluwer Academic Publishers; Rychen, D., Salganic, L. (eds) (2001), Defining and selecting key competencies. Seattle/Toronto/Bern/Göttingen: Hogrefe \& Huber Publishers. 
has lately concentrated on the two core competencies of academic skills and management skills.

The research done within this research line took place in varying partnerships with my two ROA colleagues Christoph Meng and Ger Ramaekers, and ROA fellow Catherine Ris. We made use of the European CHEERS dataset on the labour market position of the higher educated three to four years after graduation, and the Dutch University Education Monitor dataset, relating to the labour market position of university graduates eighteen months after graduation. Both datasets also contain information on self-reported competencies. From these, the three above-mentioned competencies were derived. Discipline-specific knowledge includes both the theoretical subject-specific knowledge and the discipline-specific knowledge of methods. Academic skills include such skills as learning ability, the ability to reflect, problem-solving abilities, analytical skills, and being able to record ideas and information systematically. The management skills consist of elements such as being able to plan, coordinate and organise, leadership, economic thinking, oral communication, being tolerant and taking responsibility.

\section{Figure 2}

Relational diagram of the competencies research line

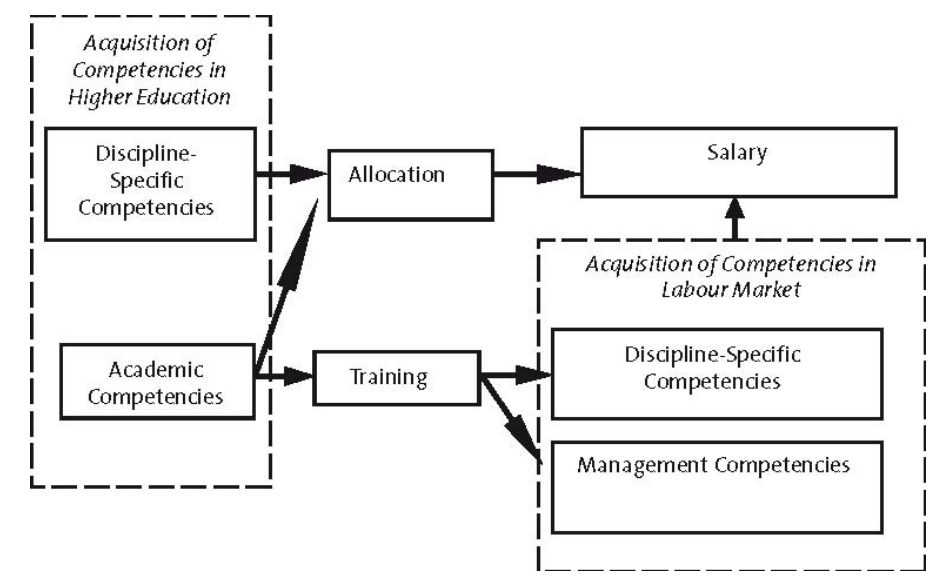


The studies that were done can be located in the relational diagram represented in Figure 2. The left-hand section of the diagram indicates how the competencies of discipline-specific knowledge and academic skills are acquired in education. The right-hand section shows the role of these competencies in the labour market. This concerns in particular their effects on the job, the related rewards, and participation in training activities in order to develop or refresh the discipline-specific knowledge or to learn new competencies, such as management skills.

Rather than discussing all the studies that have been completed, I will present a cross-section of their main conclusions. I will first discuss the role of the individual competencies in the labour market. ${ }^{27}$ Then I will deal with the characteristics of education programmes that promote the acquisition of these competencies.

Discipline-specific knowledge appears to give graduates a comparative advantage in jobs in the occupational domain of the study completed. After all, graduates who have a higher level of discipline-specific knowledge, appear to have a greater chance of finding a job within the study's occupational domain. Graduates who work in the study's own domain also earn more than outside that domain.

Graduates with a higher level of academic skills, however, have a greater chance of a job outside the domain of the study completed. Their own study is less useful there, which means that the wages are lower and they need to be able to adapt rapidly to new circumstances. Their greater learning and adaptation capabilities also result in greater participation in training and more rapid acquisition of the skills required to obtain a management position. Both participating in training activities and having a management position yield salary increases, so that there is an indirect and long-term return on the investment in acquired academic competencies.

27. This concerns the following studies: Heijke, H., Meng, C., Ramaekers, G. (2003), An investigation into the role of human capital competences and their pay-off, International Journal of Manpower, 24 (7), 750-773; Heijke, H., Meng, C., Ris, C. (2003), Fitting to the job: the role of generic and vocational competencies in adjustment and performance, Labour Economics, 10 (2), 215-229. 
Both types of competencies therefore have a strategic function for graduates in finding a position on the labour market. In essence, a high level of disciplinespecific knowledge gives graduates a good starting position in the labour market, while a high level of academic skills is important for further career development. If studies wish to give their graduates a broad perspective on the labour market, then neither of these two types of competencies should be missing in the study. So the message is that they should refrain from concentrating exclusively on disciplinespecific knowledge, and also pay sufficient attention to the development of academic skills.

I will now discuss the findings with respect to the possible contribution of education to competency development. The research that was done provides indications that management skills cannot be taught effectively in education programmes. ${ }^{28}$ For example, economists who studied business administration do not have a greater chance of having a management position eighteen months after graduation than other economists. And those who did acquire a management position, were not paid better than other economists in the same position. Work experience, also if this is gained as a student, does improve the chances of a management position. This should also be considered over a longer period, of course. For the time being, the findings merit a degree of reserve if education programmes make great pretensions in this field.

With respect to discipline-specific knowledge and academic skills, we studied the effects of various types of learning environments on the acquisition of these competencies in the education programmes. ${ }^{29}$ The difficulty here was that the partial effect of the learning environment is difficult to establish, because the

28. Heijke, H., Ramaekers, G., Ris, C. (2005), Do business administration studies offer better preparation for supervisory positions than traditional economic studies?, Education Economics, 13 (4), 315-329.

29. Meng, C., Heijke, H. (2005), Student time allocation, the learning environment and the acquisition of competencies, ROA-RM-2005/1E. Maastricht: ROA. See also Vaatstra, R., Vries, R. de (2006), The effect of the learning environment on competences and training for the workplace according to graduates, Higher Education, 53 (3), 335-357. 
acquisition of both types of competencies is by definition interconnected. After all, the acquisition of discipline-specific knowledge requires the use of academic skills and this learning process, in turn, develops the academic skills. In the analyses, we corrected for this as well as possible. We found that in an activating learning environment, such as the problem-based learning system, there is a more effective acquisition of academic skills than in other types of learning environments. Moreover, if this activating learning environment is combined with a more central role of the teacher in the transfer of knowledge, the acquisition of disciplinespecific knowledge is also more effective in this type of learning environment than in the other types. This is a great boost for the Maastricht problem-based learning system. At the same time, it presents a challenge of creating a problem-based learning environment in which the passive role of the tutor, who merely monitors the group process, is replaced by a more active contribution of a teacher who transfers knowledge. 